\title{
クロム染料に就いて
}

\section{林茂 助}

染料と堅牢度 一般的に言つて强い染料と言はれて るるものは建染染料，媒染染料(酸性媒染染料共)，硫化 染料等である。建染染料や硫化染料は共に水に不溶性染 料であり，還元によつてりユウコ化合物空形成して被染 物に染着し後酸化されて元の染料となつて布に染めつく のである。この還元の際比較的アルカリ性の强い試蔡で 處理するので特種のるの以外は羊毛，絹の如き動物性䋐 維に應用することは困難である。それで羊毛 絹の如き 動物性瀻維に對する堅审な染料としては酸性媒染染料か 最も重要なるのである。

現時すべての原料が逼迫してるる時では所有する原料 を極度に有效に利用してより有效に使用される成品を製 作するの方工業を有利に經營して行く唯一の途てある。 この意味からして隻駐軍ならびに商工省, 化學工業連盟, 化成品罳話會等力゙主張された染料生產計畫は當を得たも のと思ふ。即ち硫化染料はさしろ生產を差しひが，直 接染料ならびに酸性媒染染料等を極力熷產するといふ方 針は輸出䄉維製品との關係からしても誠に然かあるべき ことである。この現下の脚光をあびて再建途上にある酸 性媒染染料郎ちクロム染料について何か述へよとのこ と，責任甚げ重大なるを感ずるすのであるっロム染料 全般にわたり詳しく述べことはこ〉には不可能である が，筆者等はクロム染料之化學構造上密接な關聯性のあ る「クロム含有アゾ染料」(市販品ではネオラン染料 ( $\mathrm{S}$ CI)，パラチンフアスト染料 (I. G) 等。染法から言へば 酸性染料である。後に詳しく述べる)について戰爭前か ら少しく硨究して居つたのでこの種の染料を合せてクロ ム染料について少しく述ぺて見よ5と思ふ。

クロム染料とは クロム染料と通常呼ばれ て居る染料は酸性媒染染料のことであると考 ていいと思ふっクロム染料の起りは酸性染浴て 染色した被染物丟クロム後處理して染色する方 法に適する染料を先つ稱へたものと思はれるが， 現今では酸性媒染染料すなはちクロム染料と考 へる万が現實にクロム染料と乎んで居る人々の 意志にかなつたものと思ふ。そして酸性媒染染 料はクロム染料と呼ばれると同時に又酸性ク口

ム染料とも呼ばれて居る。染色の本によつてはクロム後 處理媒染染料或ひはクロム後處理酸性染料と䊈してそれ ぞれ媒染染料或け酸性染料の內に含めて分類してるるる のもある样でる。

然らは酸性媒染染料とは如何なる染料かと云らと一般 に酸性浴て動物性䋐維に染着し且つ金屬媒染した被染物 にも染着する兩方の性質を有するもの考言らのである。 主として羊毛に用ひられるが絹にる使用される。しか し木綿や人絹には浸染ては實用されない。羊毛に應用す るには一般に酸性浴で普通の酸性染料の染色法と同樣に して染色し、次に重クロム酸カリで處理する(所謂クロム 後處理法つのであるが,絹染には一般にいはゆる媒染染料 に似た染法郎ら媒染後染料で染色するのである(羊毛に

對してかくの如き染法を應用した染料は媒染染料儿入れ るのであるかう。忠媒染劑と染料とを同一染浴に入れ一 浴で染色するいは将るモノクロム染法或はメタクロム染 法と呼ばれる染法るある。更に細かに言いばクロム新染

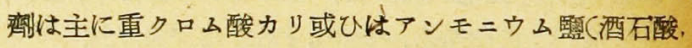
苳酸, 或ひは蠘酸の如き還元劑の存在の場合分゙多い),弗

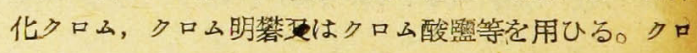
々監の代りに他の媒染劑を用ひる場合もある。例へば銅 鐵，アルミニウム其他の金屬監ぶ用ひられる。

クロム染料つ分類 クロム染料起化學構造上から分 類すると，アンスラキノン誘導體(例I)、トリフエニル メタン染料 (例II)，アゾ染料 (例 III) ダ，殆どその全部 である。例外的にクロモトロープ酸 (NV) の如く着色物 質でないるのを用ひて媒染劑で發色せしめるものるま
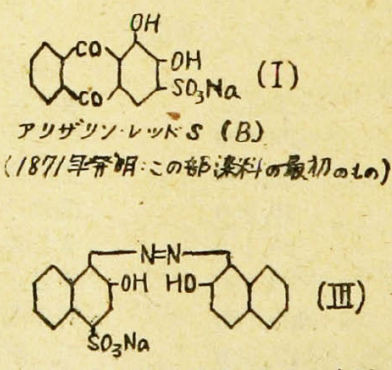

パラ4ソ・クローム・ブラック $6 B(B)$

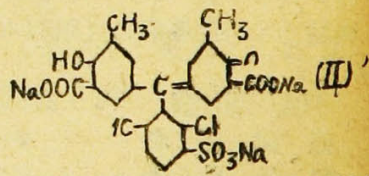

エリネワローム・アス゚ロールS (G)

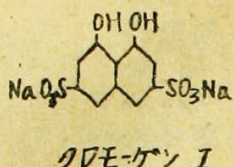

(IV) 
る。此の內でアン゙染料が特に數が多い。

ロム染料の性咓 然らばいかなる染料分クロム染 料になり得らかと云らと先つ酸性染料と同じ樣に酸性で 染着する性質を保有させるためにスルフオン酸基或はカ ルボオキシル基を有することが必要である。次に媒染性 を保有させるためには拉よそ次の 4 つの場合の何れかの 構造を有すること分必要である。(1) 染料分子內に一O H基を有してての一OH 基に對してオルト位置に他の一 $\mathrm{OH}$ 基 $-\mathrm{COOH}$ 基或ひはこれに類する基の存在する 場合。(2) ベ位圆に一OH 基, $-\mathrm{COOH}$ 基或ひはこれ に類する基名存在する場合。（3）アゾ結合に對してオル 卜位置に一OH 基の存在する場合。（4）-OH 基の代り に一 $\mathrm{NH}_{2}$ 基がある場合す媒染性を有し得ること名゙ある。

酸性染料となるに必要な基としてスルフタン酸基或は カルポオキシル基の存在焂必要であるのであるがこれ 等の基のない場合でる酸媒染料となり得ることがある。 例へば例 $\nabla$ の樣な場合である。染色された被染物の色相 は媒染前の色相とは甚でしく異なるのが普通であるが あまり變化のない場合もある。それは分子內に一OH基， 一 $\mathrm{COOH}$ 基が岕るアソ染料て酸性媒染染料になり得る場 合でアゾ基に對してォルト位置に一OH 基がなくパラ位 置にある様な場合分多いのである。例へば例 四の場合の 樣な時である。スVII場合の樣に一般的にばクロム錯化 合物を作り得ない樣な場合に於てもクロム後處理すると 堅牢度がよくなる場合があるが，この時は色相は餘り變 化しない。これは完全な錯化合物を作つてない镫據であ る。

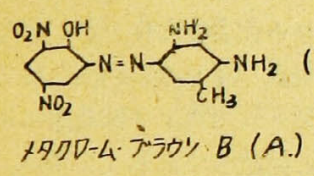

イタワローム・デラヴ・B (A.)

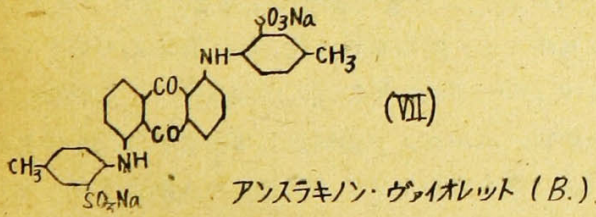

メタタロム染法 クロム染料は洗熦、日光、縮絨，

摩擦，火鸼斗等に對し甚けて堅牢ではあるがク口ム後處理 による染法は色相及び濃淡を加娍するのに多大の經驗が いる。それでその改良法として前に述べ單一染浴て染 色するメタクロム染法分發明されたのである。この方法 は 1900 年アグフア會滆で發見したのである。メタクロ ム法, エリオクロム法, 或ひはモノクロム法と稱される

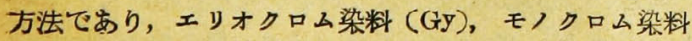

(LBH), アンスラセンクロム染料 $(\mathrm{C})$, メタクロム染料 (A-等と云ふ染料かこの種の染料である。この時使用す

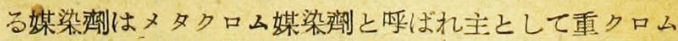
酸カリ或けアンモニウム盤等が使用される。

クロム染料の冠稱 次の樣な冠稱のついて居る染 料は皆酸性媒染染料で岁る。Acid Alizarine (M), Acid An hracene (By), Acid Chrome (By), Alizarine Direct (M), Anthracen: Chrome (C), Anthraquinone (B), Chrome Fast (SCI), Diamond (By), Griochrome (Gy), Metachrome (A), Monochrome (LBH), Palatine Chrome (IG), Solochrome (BDC), Superchrome (NAC), Mitsui Prichrome (Mitsui), Sunchromine (JDC, Diachromine (Mitsubishi), Mitsui Chrome (Mitsui), Mitsui Sanbai (Mitsui).

クロム染料のヂアソ゚及びアソ゚成分 クロム染料とな り得るアゾ染料のヂアゾ成分としては4ークロルー2ーア ミフフェノール,4ーニトロー2ーアミノフェノール, 5 ニトロー3ーアミノー4ーオキシー1ーメチルペンゾール, 2 一ナミノフェノールー4-スルフオン酸, 6一=トロー2 ーアミノフェノールー4ースルフオン酸.ピクラミン酸の 如きオルトアミノフェノール又はその =トロ灭びクロル 誘道體が多い。この他ザリチル酸及びクレッ゙チン酸のア ミノ訜導體, アンスラニール酸,ナフ多リン系としては 1ーアミノー2ーナフトール-4-スルフォン酸更び其の 6ーニトロ誘導體等分多く用ひられる。アメ゙成分〔カップ リング成分) としてはザリチル酸 クロモトロープ酸の 如きべリヒドロオキシ化合物, $\beta$ (VI) ナフトール，クレゾチン酸, $\beta$ 一ヂ ケトン， $\beta$ ーケトカルボン酸エステ ル、ピラゾロン誘導體, $\mathrm{m}$ 一ヂアミ 等である。

市販シロム染料（アゾ系） 比較的有名な個々の染 料の各成分を表示すると次の如くである。 アシッド・アリザリン・ブラック $\mathrm{R}(\mathrm{M})=2$-アミノ一 6一ニトロフエノールー4 スルフォン酸 $\rightarrow$ スーフト $-\pi$

アリザリン・エロー GG(M: =メタニトラニリンーザリ チル酸

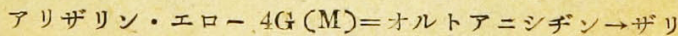
チル酸

アリザリン・エロー R (By) =パラニトラニリンーザリ チル酸

アンスラセン・クロム・ブラック $(\mathrm{C})=3$ ーアミノー2-

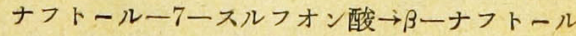


アソフクシン $\mathrm{B}(\mathrm{By})=$ トルイヂン $\rightarrow$ ヂオキシ $\mathrm{S}$ 酸

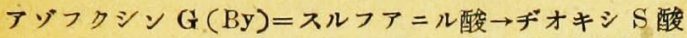

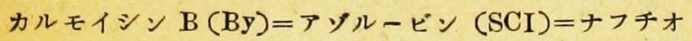
ン酸 $\rightarrow \mathrm{NW}$ 酸

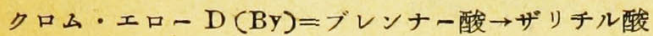

クロムトロープ $6 \mathrm{~B}(\mathrm{M})=$ パラスミノアセタアニリド

クロムトロープ酸

クロムトロープ $8 \mathrm{~B}(\mathrm{M})=$ ナフチオン酸 $\rightarrow$ ロムトロー ブ酸

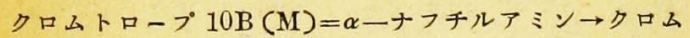

トロープ酸

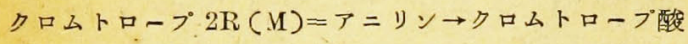
ダイアモンド・ブラック PV $(\mathrm{By})=1$ オキシー2ーア ミノベメゾールー4ースルフォン酸 $\rightarrow 1,5$ 一ヂオキシナフ タリン。<smiles>CS(=O)(=O)NC1CCC(O)C(O)C1NNC1CCCCC1O</smiles>

なる構造を有し普通のカップリングの法則と異なり $\mathrm{OH}$ 基に對してォルト位置にカップルする。1902年 Kaln の 發見て黑色クロム染料の內で最も美しいものの一つであ る。 $\mathrm{OH}$ 基に對してオルト位置にカップルナる特別の例 はエリオクロム・ブルウ・ブラック $\mathrm{B}(\mathrm{G} y)$, エリオク ロムブラック T ( Gy) の場合にも見出される。 ダイアモンド・エロー $\mathbf{G}(\mathrm{By})=$ タタアミノ安息香酸 $\rightarrow$ ザリチル酸

ダイアモンド・エロー R ( By)=オルトアミノ安息香酸

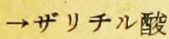

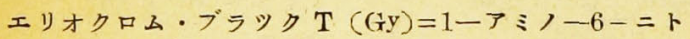
ロー2-ナフトールー4一スルフオン酸 $\rightarrow 1$ ーナフトー ル

エリオクロム・ブルウ・ブラック $\mathrm{B}(\mathrm{G} y)=1 ー ア ミ ノ$ -2ーナフトールー4ースルフオン酸 $\rightarrow 1$-ナフトール

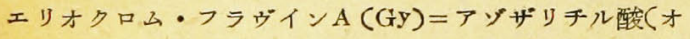

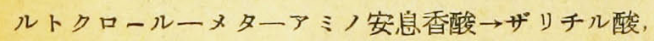

後にアルカリにて CIを OHに變へる)

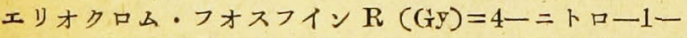

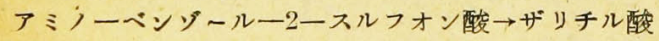
メタクロム・ブラウン $\mathrm{B}(\mathrm{A})=$ ピクラミン酸 $\rightarrow$ ターフ

エニレンヂアミン及び他のヂアミン

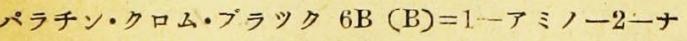

フトールー4ースルフオン酸 $\rightarrow \beta$ ーフトール

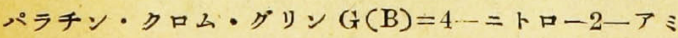

ノフエノール $\rightarrow \mathrm{H}$ 酸

ヴイクトリア・パイオレット $4 \mathrm{BS}(\mathrm{M})=$ パラーニトラニ

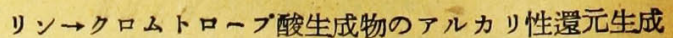
物クロム染料中にはヂスアゾ染料もある。 アンスラセン・エロ $-\mathrm{C}(\mathrm{C})=$ チオアニリンスザリチル酸 ダイヤモソド・ブラック $\mathbf{F}(\mathbf{B y})=2$ 一オキシ 5 -フミ ノベンゾールー1ーカルポン酸 $\rightarrow 1$ ーフチルアミン 1ーナフトールー5一スルフォン酸。1899年Lauch等の 發見て黑色クロム染料の始めてのものである。

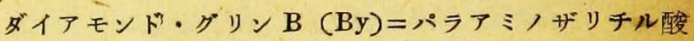

$\rightarrow a$ ナフチルアミン $\rightarrow 1,8$-ヂオキシナフタリンー4 ースルフオン酸。

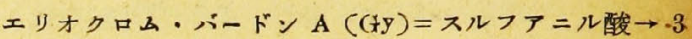

ーアミノー4ークレゾールー2-ナフトール。

トリフエニルメタン染料及びアンスラキノン系の酸性 媒染染料の實例はこれを割愛する。

クロム含有アゾ染料の發明モノクロム染法の發 明後十敖年にして染料分子内にクロムを導入した染料うう 發明された，染法からしては酸性染料であるが化學構造 から見るとクロム染料と同一のものであるからこ〉に述 ベることとする。スキスのシ バ到のパンフレット (Soc. Chim. Ind. in Bale. 1864〜1926. 28頁)によれば|1 914 年にクロム㽇を作り得る群を有する染料の或種のク ロム化合物は普通の酸性染料と同じ万法で動物性瀻維を 染色し得るといふことを覺した。これより少し前に R. Bohn は酸性吸暗劑の存在で或種のオルトオキシア ゾ染料をクロム酸化物で處理してクロム整を作り得る群 を有するアゾ染料のクロム化合物を作つた。そしてこの ものは植物性繊絓の捺染及びインクに利用し得ることを 知つた かくしてバヂッシ耐でカコ捺染用にエルガン 染料として市販した と記載してあると Ber., 56, A. 29 (1923) 寥照)。篚者の調查によるとオキシアンス キノンスルフオン酸のクロム化合物に䦪するバヂッシ社 の特許は 1900〜1914 年の間にかなり多く, これ等引゙ ルガン染料，エルガノン染料として市販されたものと想 像される。尤子オルトアミノフエノール類とオキシ安息 香酸とのカツプリングによつて出來たアゾ染料もこのエ ルガン染料，エルガノン染料の中に含まれて居ると思 ふ。 染料の水に可溶性でンク等に使用し得られるク口 ム含有アゾ染料の製法が特許に最初に表れたのはパヂッ シ社の D. R. P. 282987 (1915 年 2 月) である。そし てシバ社の D. R.P. 338086 (1921 年 5 月) に初めてア ソ染料のクロム化合物が動物性瀻維を酸性浴から染色し 得るといふ事筫が記載されてある。シバ刓のパンフレッ ト (Ciic. No. 355) によればネオラン染料を 1920〜192 
1 年に初めて市場に出したと書いてある。とれと殆ど同 時に I.G社でるバラチン・フラスト染料を市眅した。

吾國には大體ジ行で販賣した直後に輸入された樣で あるが始めは染色の際に比較的多量の硫酸 $(6 \sim 8 \%)$ を 使用するので羊毛を損ずると誤認されて其の使用量從つ て晞入額け餘り多くなからた。しかし硫酸に上る繊維の 損傷は問題にする程でなく且つパラチン・フアスト・・ ルト○液狀 (1932 年), ネオランソルトNS】 (1933 年) 及びネオランソルト II (1934 年) 等を 6〜7\%使用するこ とにより硫酸の量を $5 \%$ に減じ得る樣になり,この種染 料の使用量が等激にこの年代頃から䞇加した。等者等は 1933〜4 年頃からクロム含有アソ染料の合成研究を行ひ 1 2 の日本特許 $(116618 ， 116619$ (昭11)) を得, 昭和 11〜12 年頃には㫍土谷曹達株式會社によつて工業化さ れた。

クロム含有アゾ染料の特長 然らば羊毛用クロム 合有アソ染料の染色上の利點は如何といふに大略次の通 りである。染色操作が極めて簡單て大體酸性染料と同樣 である。硫酸を 6〜8\%使用し1〜1.5 時間煮沸して完全 に發色せしめるのである。この際芒硝等を加へる場合る ある。然るにその堅牢度は日光, 洗濯, 縻察, 汗等に對 し酸性媒染染料と殆ど同一である。しか子酸性媒染染料
の如くに色斑を生ずることなく均一に染色する。また色 合せ極めて容易であり且つ石灰，鐵分等に對し影響せら れること分少い。缺點を言へばクロム染料です同樣であ るが牙へた明色を缺くことである。すしも製造價額が少 しく低廉に行く椂になればク口ム染料の大多數のものは 分子內にクロムを含有した，染色上から言へば酸性染料 に入るべきいはゆるネオラン染料型のものに置き換へ得 るすのと信ずる。

更に分子內にクロム原子を錯化合物として含有するア ブ染料に人絹，木綿用のものも㐫る。市販品ではリガン 染料 (SCI) と稱されるすのがこの部に痛する。筆者等 もこの部のるのも既に研究したのであるが今氙は動物性 纎維用にのみ言及するとととする。

なほラナン゙ール染料 (SCI) は銅合有アゾ染料であり ネオラン淘料の如き染色泆で染色されるがこれる制愛す る (「Sos. Chim. Indus ry in Basle. 1864 1926」 29 頁參照)。

クロム含有アゾ染料の化學構造 クロム染料分媒 染劑により被染物に染着した際の化學構造は染料分子內 にクロムを錯化合物として導入したネオラン染料型と同 じ㨾な化學構造炎有するものと考へられて居る。そして

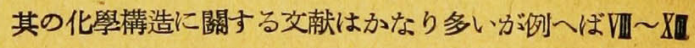

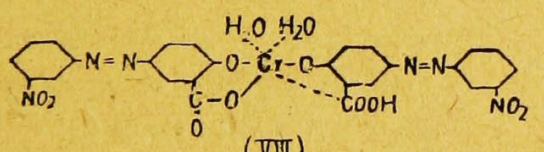

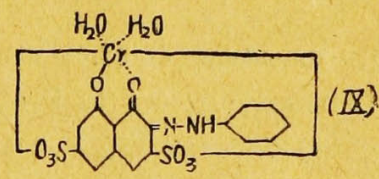

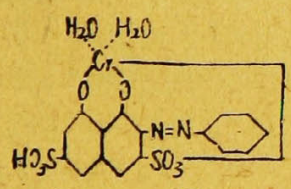

(区)

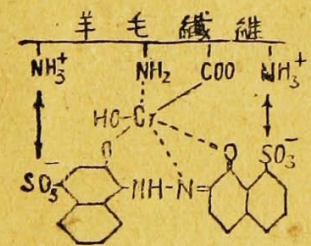

(XI)

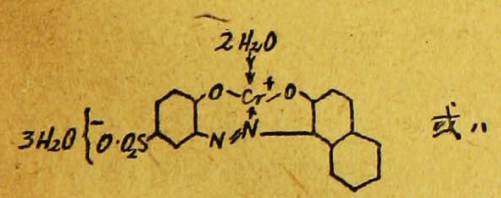

(XII)

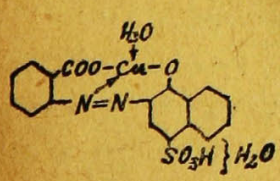

(XV)

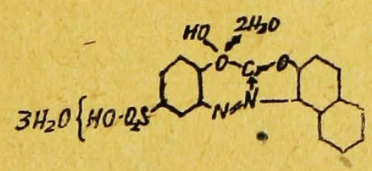

(XIII)

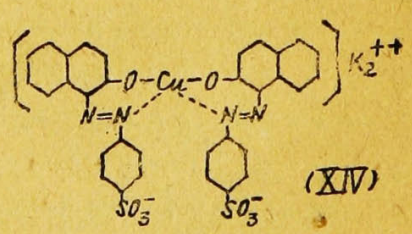

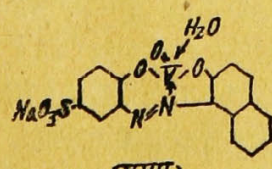

(XVII)

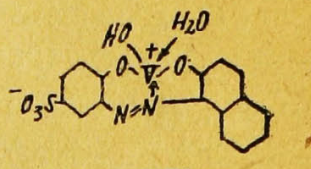

(XVIII) 
の如き構造を有するものとして說明されて居る(學協, 15，71 (昭15)；J. Chem. Soc., 1939， 823)。銅. 了 ルミニウム，バナヂウム錯監に關しても XIN〜XVIII の如 き構造を有すると云ふ報交がある (J. pr. Ch., 149, 217, 238 (1937) ; J. Ch. Sos., 1938, 292 ; ibid, 1940, 603, 608, 1064。

筆者等はクロム含有アゾ染料を合成しその性質を吟味 して見たが XIX〜XXII の如き構造を有するにあらずや と想像してるる。しかし確かな理論的根㹉があるるのでは ない。クロ入媒染及びク口ムを染料分了內に導入する際 の化學反應は場合によつてかなり複雜で生成物の覓の構 造は今のところはつきりして居らないと云ふ方が本當と 思はれる。
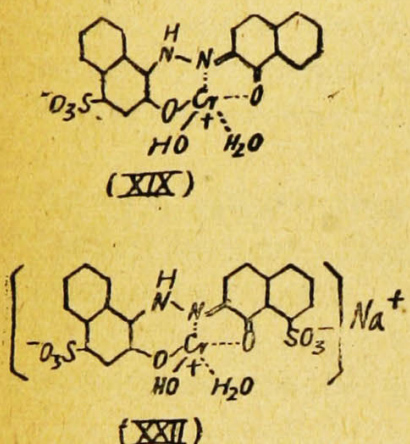

(XXII)

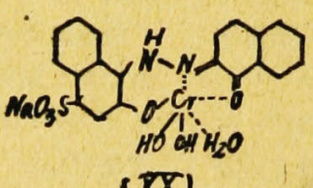

(2X)
合は此較的少いものと信ずる。ネオラン・ヴアイオレッ

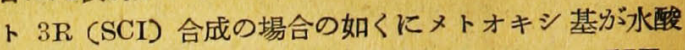

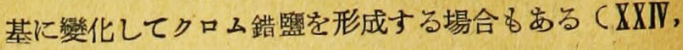
有機合成, 2, 報 21 (昭19))。

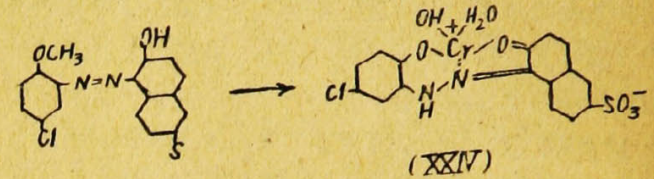

さきにも一寸一言したが例へば VII の様にアソ基に對 してオルト位置に一OH 基のない場合は媒染後の色相及

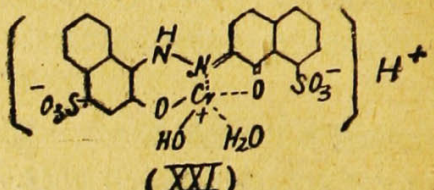

(XXI)

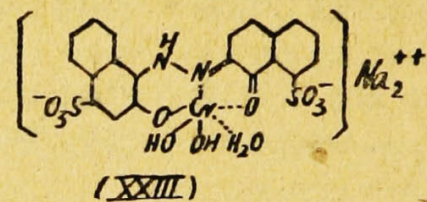

Albrecht 及び Rosenhauer 等 (Z. angew. Chem., 41, 617(1928); Rosenhaver, Wirth, Königer ; Ber, 62，2717 (1929) の研究によれば纎維にクロモトローブ 酸(無色)(クロモーゲン I (M))を四着せし.め, 後クロム 酸監でクロム後處理すると織維を褐色に染着するが，こ れは 8一オキシー1, 4一ナフトキノンー3,6一ヂスルフ オン酸の着色ラックで染色されたるのとして說明して居 る。またクロムトローブ FB(M) はカルモイシン B (By)，アソルービン (SCI) 等とも稱され 1883 年 Witt の發見であり，最初の酸性媒染染料であるがその組成は

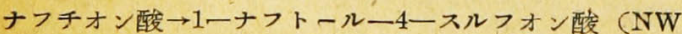
酸) である。このものはクロム酸然で處理した場合のみ に青色ラックを與へクロム筒の場合には與へない。そし てこの青色ラックは 1ーアミノー2ーナフトールー4ース ルフオン酸 $\rightarrow 1$ ーフトールー4ースルフオン酸の着色ラ ックと同一物であるからデアゾ成分の 2 -位置に OH基 か導入されたるのとして說明して居る。かくの如くにク ロム媒染の場合には單なる錯轓形成のみでなく酸化も起 る場合がある。しかしクロム含有アソ染料を還元分解し て其の組成を吟味した筆者の經憸によると酸化の起る場
び分子內にクロムを導入して得られた染料の色相はクロ ム處理前とは餘り變化がない。又アり゙基に對してオルト 位置に一- $\mathrm{OH}$ 基が 1 個の場合や $-\mathrm{NH}_{2}$ 基による錯化合 物の中では再結晶を繰り返す內に金屬錯化合物は金屬原 子を分裂して金屬を含まぬ元物質に變化する場合が多 い。しかし多くの場合は錯化合物は普通の化學反應では 錯㢳のまま反應し得る位相當强固に結合して居る(學協, $17 ， 46 ， 51 ； 18 ， 253 ， 257$; 有機合成，2，報 21 ，報 $24 ； 3$, 報 $44,36,49 ; \mathbf{4}$, 報 $5 ， 9 ， 17$ 參照)。

市販クロム含有アゾ染料 昭和 16 年の外國文献入 手出來なくなつた時までの市販ネオラン染料は約 71 種 パラチンフアスト染料約 70 種であり，これを色別する とネオラン染料，パラチンフアスト染料 : 黃色 6,12 ; 橙 色 6,5 ; 赩 12,11 ; 褐色 4,4 ; 紫色 5,3 ; 海青色 6,6 ; 青色 9,12 ; 黑色 7,9 ; 灰色 7,1 ; 綠色 7,6 ; 助劑 2,1 ; 合計 71,70 となる (學協. 15,71 (昭15) 參照)。

クロム含有アゾ染料つ特許 羊毛用クロム含有ア ゾ染料についての特許は甚げ多く Friedländerの染料に 關する特許集錄の本に載つて居る分でけでる第 11 卷以 後續々と出で居り第こ卷 (1932〜3年頃までの分) まて 
К總數 130 前後あり主としてIG 及び SCI の特許であ る。この外アニスラキノン系区びトリフエニルメタン采 のクロム含有染料の特竍數も多數ある。また木綿, 人絹 用のクロム含有アゾ染料の特許は羊毛用に比較しては少 いが約 30 そ數へる。銅その他の金屬含有アゾ染料の特 許も相當見えて居る 最近の米國ヶミカル・アブストラ クッ誌上には今なほ多くの特許が載つて属る所を見ると 現在まてには相當多數の特許があるものと思ふ。

以上の特詐に表れた實驗例からデアり゙成分とアジ成分 と党擧げると本交末尾の表の如くである。但し紙數の都 合でその一部を表示するに止めた。

ネオラン染料の化學組成 篚者等の研究によつて 市販品の主成分の化㠘構造の明になつたものは本文末尾 の表の如くである(未發表)。

\section{染料分子內にクロム原子を導入する方法 染料}

分子内にクロムを導入する一般方法与なはちクロム錯化 合物の合成方法は染料とクロム化合物と共に常医で加熱 するか或ひは加是釜で加熱するのである。クロム化合物 としては無機及び有機化合物何れる用ひられる。また特 別の方法として有機化合物のクロム錯䗟を゙ップリング

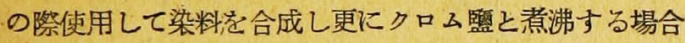
あある。筆者等はヂアり゙化反應が普通の方法では進行し。 嚾い場合例へば 1ーアミノー2ーナフトールー4ースルフ オン酸のヂアゾ化の場合の如き時にはクロム䤈を添加す れば銅，亞鉛 ニッケル，水銀．アルカリ土金䙓等の添 加の場合と同樣ヂアゾ化反應よく進行することを知つた ので先づクロム医篮を源加してヂアソ化し次でカッブリン グを行ひ染料を分離することなしに過量のアルカリを加 へて加熱してクロムを導入する方法を見出した（日本特
許前記)。

普通クロム鍇化合物合成に使用されるクロム化合物は

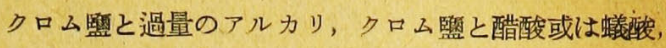
クロミクロメート等である。特許に表れたクロム化合物 を列記すると次の如くでする。

弗化クロム水溶液とガラス粉末。 $\mathrm{K}_{2} \mathrm{CrO}+\mathrm{N}_{2} \mathrm{~S}_{2} \mathrm{O}_{3}$ $+\left(\mathrm{NH}_{4}\right) \mathrm{SO}_{4}$ 或ひは $\mathrm{Na}_{2} \mathrm{Cr}_{4}+\mathrm{O}_{7} \mathrm{Na}_{2} \mathrm{~S}_{3}$ 郎ちクロ クロマート。議酸クロムと蟻酸。 $\mathrm{K}_{4} \mathrm{CrC}_{4}+\left(\mathrm{NI}_{4}\right)_{5} \mathrm{SO}_{4}$ 硫酸クロム。クロム明攀。硫酸クロムと醋酸。クロム明

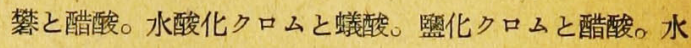
酸化ク口ム。水酸化クロムと過量の苛性》一ダ。水酸化 クロムと過量の苛性ソーダとグリセリン。蟑酸クロムと 過量の苛性ソーダ。湶酸クロムと酳酸ソーダ。弗化クロ ムと醋酸ソーダ。弗化クロムと蟻酸ソ一ダ。䄈酸クロム と蟻酸ソーダ。蟻酸とクロム酸化物。弗化ク口ムと苳酸

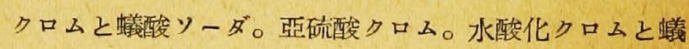
酸と囦酸と共に意沸後砂糖と苛性ソーダとを加へ更に加 熱。弗化クロムと蟻酸り一ダと共に加熱後砂糖と菏性〉 ルカリとを加更に加熱。螦酸クロムと加熱後砂糖と苛 性ソーダとを加へ更に加熱。蟻酸クロムと蜻酸りーダと 共に加熱後に菏性りーダを加へて更に加熱。硫化ナトリ ウムと水酸化クロムと亞硫酸セルロロースと共に加熱。へ

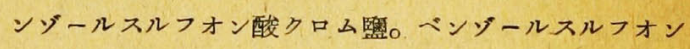

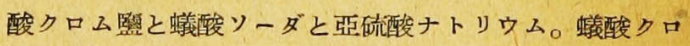
ムと嗍砂。ナフタリンー1,5-ヂスルフォン酸クロム暃。 クロム含有染料と煮沸, 水酸化りロムとクロル醋酸と加 熱後砂糖と苛性ソーダとを加へ更に加熱。カップリング の際に水酸化クロムを存在させカップル後にアルカリ性 として煮沸。(昭和 23 年 1 月 31 日，東京工業大學）

\section{ダアゾ成分}<smiles>O=[N+][C-]1CCCC(O)C1</smiles><smiles>CC1CCC(O)C(N)C1</smiles><smiles>CC1CCC(N)C2CCCCC12</smiles><smiles>NC(O)C1CC([N+](=O)[O-])CC([N+](=O)[O-])C1</smiles><smiles>NC1CC(S)CCC1O</smiles><smiles>CC1CCC(O)CC1</smiles><smiles>CC1CCC(O)C(N)C1</smiles><smiles>NC1CCC(=O)C2CCCCC12</smiles><smiles>CC1CC(N)C(O)C(N)C1</smiles><smiles>CC1CCC(C)C2CC(=O)CCC12</smiles>

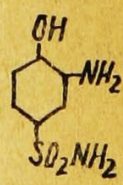

$\mathrm{O}_{2} \mathrm{NH}_{2}$ 
フッ成介(カップリワ・成分)

$\bigcirc_{\mathrm{OH}}^{\mathrm{CH} \mathrm{H}_{3}} \mathrm{O}_{\mathrm{OH}}^{\mathrm{CI}} \mathrm{Cl}_{\mathrm{OH}}^{\mathrm{CH}_{3}} \mathrm{O}_{\mathrm{OH}}^{\mathrm{OH}} \mathrm{O}_{\mathrm{COOH}}^{\mathrm{OH}} \mathrm{O}^{\mathrm{NHCOCH}}$

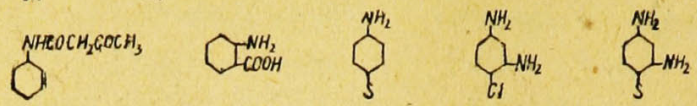

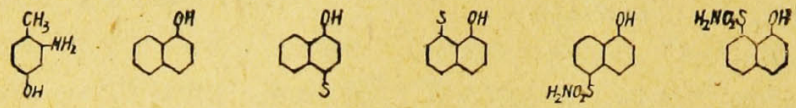

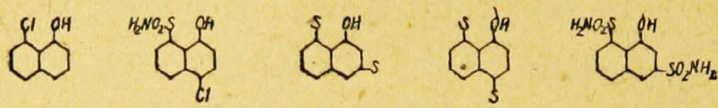

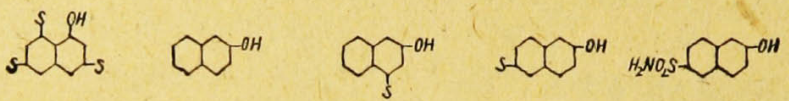

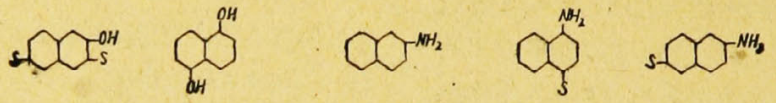

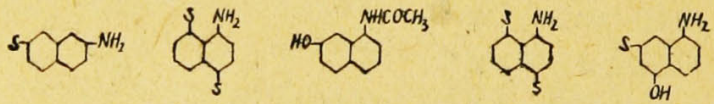

(2)

$\underbrace{-\mathrm{NH}_{2} \mathrm{CH}_{2} \mathrm{COOH}}_{\mathrm{OH}}{ }_{\mathrm{OH}}^{\mathrm{S}} \mathrm{CHHO}_{2}^{-\mathrm{S}}-\mathrm{CH}_{3}$

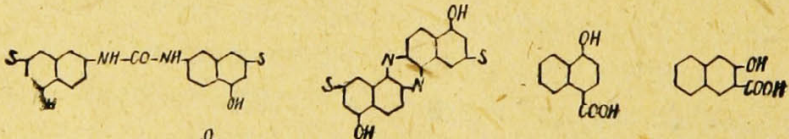
"rooc coOH

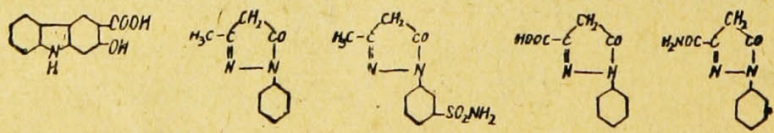

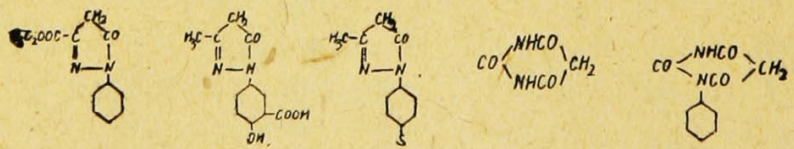

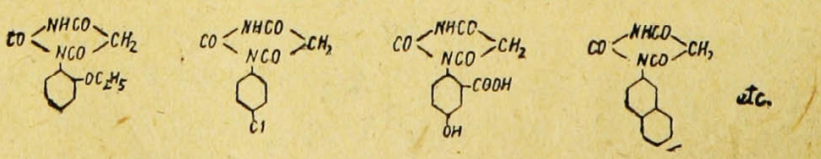




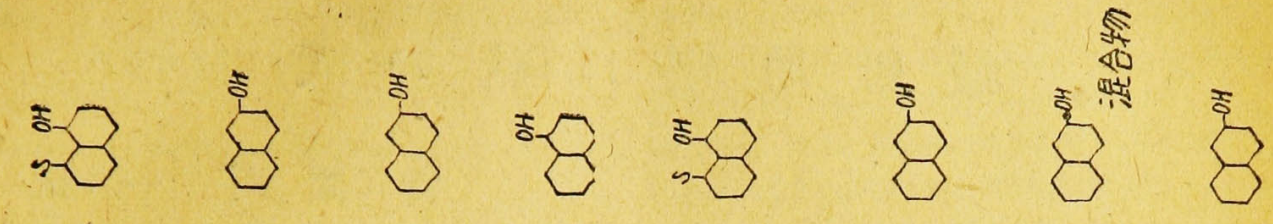
111111111

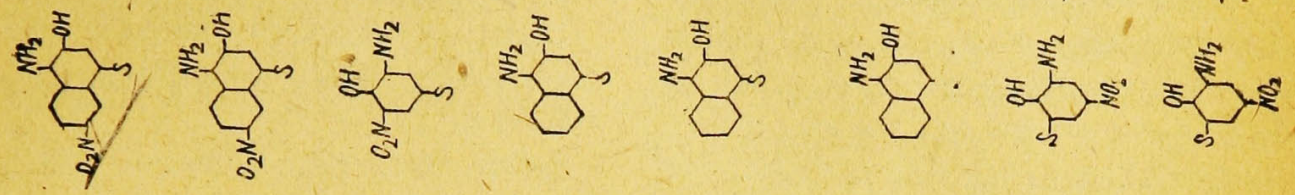

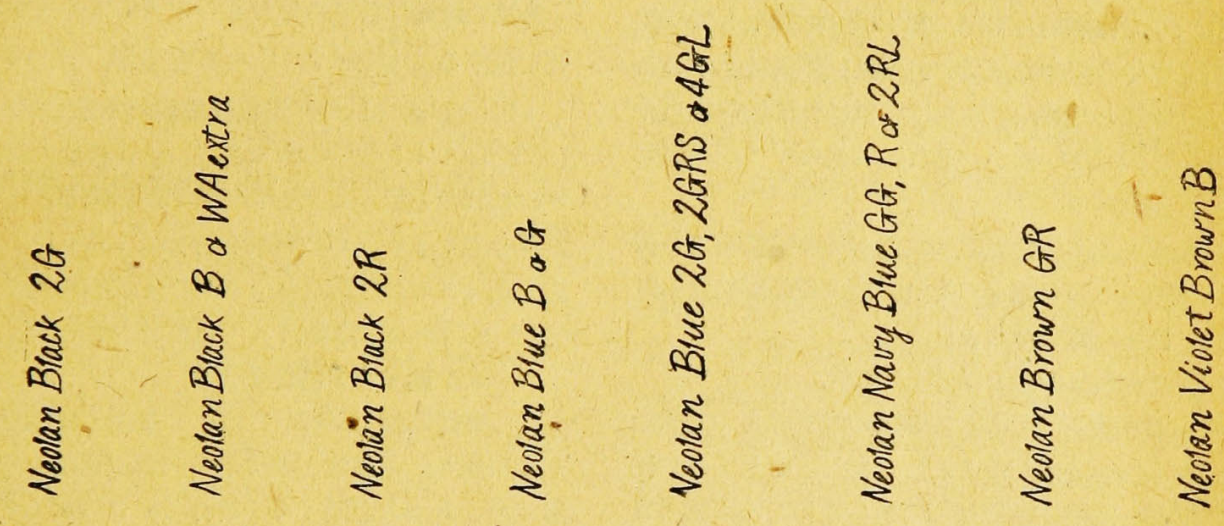

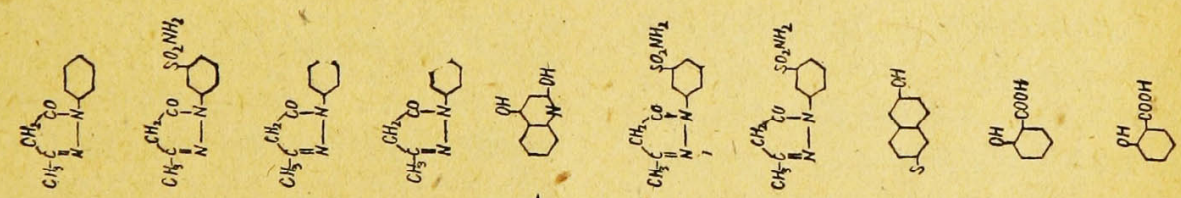
1 11.11 .11111

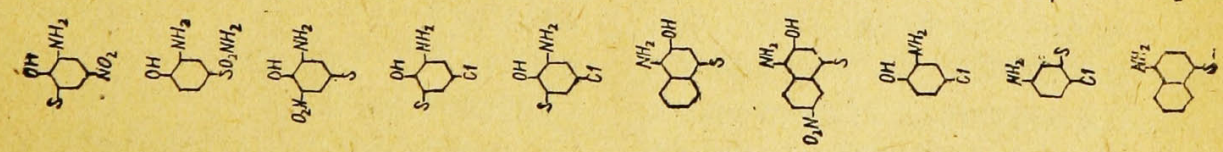

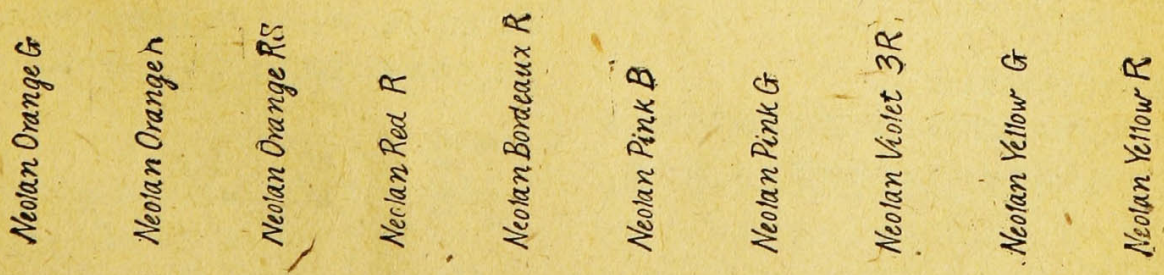

